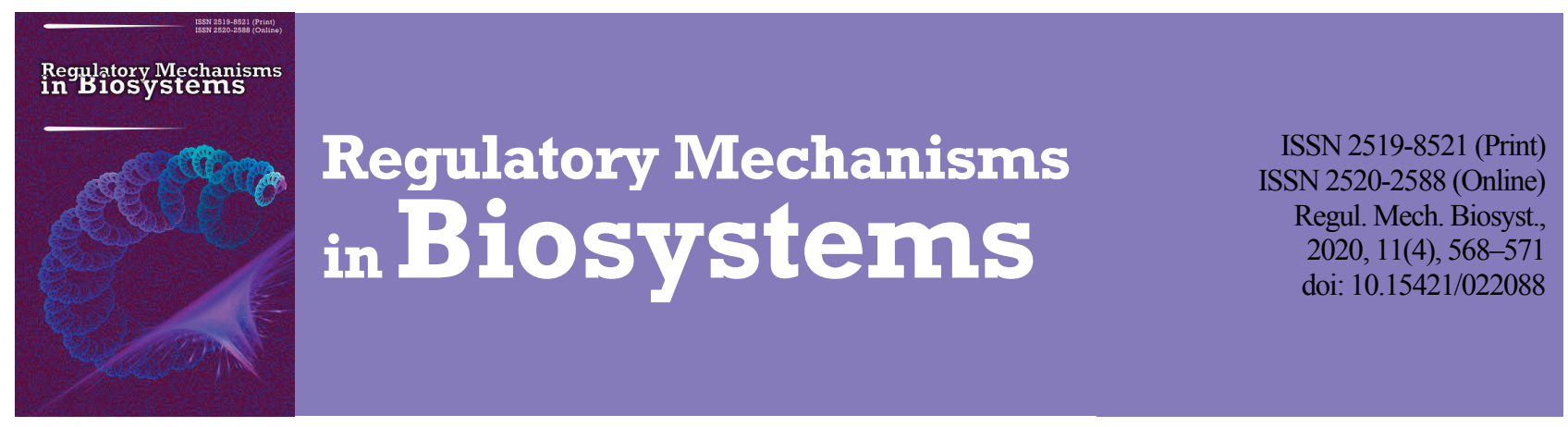

\title{
The effect of astaxanthin and lycopene on the content of fatty acids in chicken egg yolks
}

\author{
L. V. Shevchenko, V. A. Davydovych, V. O. Ushkalov, S. V. Midyk, V. M. Mykhalska \\ The National University of Life and Environmental Sciences of Ukraine, Kyiv, Ukraine
}

Article info

Received 25.10.2020

Received in revised form 22.11.2020

Accepted 23.11.2020

The National University of Life and Environmental Sciences of Ukraine,

Heroüv Oborony st., 15

Kyiv, 03041, Ukraine.

Tel:+38-050-193-10-29.

E-mail:

shevchenko_laris@ukr.net

\begin{abstract}
Shevchenko, L. V., Davydovych, V. A., Ushkalov, V. O., Midyk, S. V., \& Mykhalska, V. M. (2020). The effect of astaxanthin and lycopene on the content of fatty acids in chicken egg yolks. Regulatory Mechanisms in Biosystems, 11(4), 568-571. doi:10.15421/022088
\end{abstract}

Carotenoids that do not have provitamin activity - lycopene and astaxanthin can accumulate in the yolks of chicken eggs and give them colour, as well as affect the metabolism of lipids and fatty acids, which determine the biological value and functional capacity of such products. The aim of this study was to determine the fatty acid composition of egg yolk lipids by adding oily extracts of lycopene (20, 40 and $60 \mathrm{mg} / \mathrm{kg}$ feed) or astaxanthin $(10,20$ and $30 \mathrm{mg} / \mathrm{kg}$ feed) to the diet of laying hens. 45 High Line W36 chickens at the age of 24 weeks were used for the experiment. It was found that the addition of lycopene at doses of $20,40 \mathrm{and} 60 \mathrm{mg} / \mathrm{kg}$ and astaxanthin at doses of 10,20 and $30 \mathrm{mg} / \mathrm{kg}$ of feed for 30 days did not significantly affect the ratio of saturated and most monounsaturated fatty acids in egg yolks and $\Sigma$ SFA and $\Sigma$ MUFA. Lycopene at a dose of $20 \mathrm{mg} / \mathrm{kg}$ of feed reduced the content of cis11-eicosenoic acid, and astaxanthin at a dose of $10 \mathrm{mg} / \mathrm{kg}$ of feed reduced the content of palmitoleic acid by increasing the proportion of cis-10-heptadecenoic acid in the lipids of egg yolks. Addition of lycopene to the feed of laying hens at a dose of $20 \mathrm{mg} / \mathrm{kg}$ of feed caused a decrease in the particles of linoleic, which belongs to $\omega 6$ PUFA, and cis-eicosenoic acids. Astaxanthin enrichment of the diet of laying hens at a dose of $30 \mathrm{mg} / \mathrm{kg}$ reduced the proportion of cis-4,7,10,13,16,19-docosahexaenoic acid, which belongs to $\omega 3$ PUFA, in the lipids of the yolks. $\Sigma$ PUFA decreased in the lipid fraction of yolks only under the influence of lycopene supplements at a dose of $20 \mathrm{mg} / \mathrm{kg}$ of feed. Feeding of laying hens with lycopene and astaxanthin supplements did not affect $\Sigma \omega 3$ PUFA and $\Sigma \omega 6$ PUFA. Lycopene at a dose of $20 \mathrm{mg} / \mathrm{kg}$ decreased, and astaxanthin at a dose of $30 \mathrm{mg} / \mathrm{kg}$ of feed increased $\omega 3 / \omega 6$ PUFA in lipids of egg yolks. The results of the research can be used to select oils in combination with carotenoids of natural origin in the diet of chickens during the creation of a model of enrichment of egg yolks by individual representatives of $\omega 3$ PUFA and $\omega 6$ PUFA.

Keywords: astaxanthin; lycopene; chicken eggs, yolks, fatty acids.

\section{Introduction}

It is known that chicken eggs are a source of nutrients and biologically active substances that are desirable in the human diet (Keum et al., 2018). Eggs contain valuable proteins - ovalbumin, ovotransferrin, as well as lysozyme, which are concentrated in egg white, as well as fosvitin, carotenoids, triglycerides and fatty acids found in egg yolk (Danchuk et al., 2019; Yu et al., 2019). Enrichment of edible eggs with carotenoids that do not have provitamin activity: lycopene or astaxanthin, is associated with their effect on the content and profile of yolk lipids. In recent years, consumer demand for healthier food has confirmed the interest in changing the fatty acid profile of egg yolks (Shinn et al., 2018). Fatty acids, especially omega-3, are necessary for normal growth and development and play an important role in the prevention and treatment of coronary heart disease, hypertension, inflammation, autoimmune disorders and cancer in humans (Ehr et al., 2017; Godos et al., 2020). Researchers agree that the optimal ratio of omega- 6 to omega- 3 fatty acids should not exceed 2:1-4:1. Imbalance in fat nutrition (excessive omega- 6 and insufficient omega-3) is a major cause of many chronic diseases, including cardiovascular disease, cancer, inflammatory diseases, autoimmune diseases and many physiological disorders (Boschetti et al., 2016). Therefore, the study of the effect of different doses of lycopene and astaxanthin of natural origin on the lipid profile of chicken egg yolks is relevant. Enrichment of eggs with lycopene or astaxanthin helps the yolks not only to obtain an attractive colour for consumers, but also to optimize the antioxidant composition (Nimalaratne \& $\mathrm{Wu}, 2015$ ) and improve their nutritional value by changing the ratio of fatty acids. Therefore, the aim of our study was to investigate the effect of lycopene and astaxanthin in different doses on the fatty acid composition of lipids in egg yolks.

\section{Materials and methods}

All experiments were performed in compliance with the requirements of the European Convention for the Protection of Vertebrate Animals Used for Scientific Experiments or Other Scientific Purposes of 1986, as well as the Law of Ukraine "On Protection of Animals from Cruelty" of 21.02.2006 No 3447-IV.

The experiment was conducted on the basis of the Faculty of Veterinary Medicine of the National University of Life and Environmental Sciences of Ukraine. For this purpose, 45 14-week-old High Line W36 laying hens were purchased from Yasensvit LLC, Kyiv Region, Ukraine. The laying hens were divided into three groups according to the principle of groups-analogues: 15 heads in each and kept in cage batteries with 5 heads in each. After reaching the peak of egg laying at the age of 23 weeks, the experiment was started which lasted 90 days, the scheme is given in Table 1. Laying hens were fed lycopene supplements in the form of $6 \%$ oil extract extracted from tomatoes, produced by LycoRed (Israel), as well as astaxanthin supplements $-10 \%$ oil extract obtained from the biomass of Haematococcus pluvialis algae produced by ALGAE Technologies (Israel). Feeding of chickens was provided with complete feed (Table 2). From days 1 to 30 of the experiment, the laying hens were fed an average of $91 \mathrm{~g}$, and from 31 to 90 days $-97 \mathrm{~g}$ of feed per head per 
day. Experimental diets were prepared for 4 days, the feed mixture was mixed and stored in airtight food plastic containers. Watering of chickens was carried out at will with the use of cup drinkers. Daylight was 16 hours, darkness -8 hours, light intensity was 30 lux. The indoor air temperature was maintained at $21-23^{\circ} \mathrm{C}$, and the relative humidity was $60-62 \%$.

Table 1

Scheme of the experiment

\begin{tabular}{|c|c|c|}
\hline \multirow{2}{*}{ Group } & \multicolumn{2}{|l|}{ Diet } \\
\hline & $31-60$ days & $61-90$ days \\
\hline Control & $\begin{array}{c}\text { Basic } \operatorname{diet}^{1}+0.33 \mathrm{~g} / \mathrm{kg} \text { Basic } \operatorname{diet}^{2}+0.66 \mathrm{~g} / \mathrm{kg} \\
\text { of refined sunflower oil of refined sunflower } \\
\text { oil }\end{array}$ & $\begin{array}{l}\text { Basic } \operatorname{diet}^{3}+1.0 \mathrm{~g} / \mathrm{kg} \\
\text { of refined sunflower } \\
\text { oil }\end{array}$ \\
\hline Licopene & Basic $\operatorname{diet}^{1}+20$ lyco- Basic diet ${ }^{2}+40$ lyco- & Basic $\operatorname{diet}^{3}+60$ lyco- \\
\hline
\end{tabular}

diet pene $\mathrm{mg} / \mathrm{kg}(\mathrm{LP} 20)$ pene $\mathrm{mg} / \mathrm{kg}$ (LP40) pene $\mathrm{mg} / \mathrm{kg}$ (LP60)

Astaxanthin Basic diet ${ }^{1}+10$ astax- Basic diet ${ }^{2}+20$ astax- Basic diet ${ }^{3}+30$ astaxdiet anthin $\mathrm{mg} / \mathrm{kg}$ (AST10) anthin $\mathrm{mg} / \mathrm{kg}$ (AST20) anthin $\mathrm{mg} / \mathrm{kg}$ (AST30)

Note: the basic diet, the same superscripts 1,2,3 show the same content of refined sunflower oil in the diet.

Table 2

The composition of the basic diet for laying hens

\begin{tabular}{lc}
\hline \multicolumn{1}{c}{ Diet components } & Component content, $\mathrm{g} / 100 \mathrm{~g}$ \\
\hline Com & 50.085 \\
Wheat & 9.000 \\
Soybean meal & 17.900 \\
Sunflower meal & 9.600 \\
Limestone & 11.400 \\
Monocalcium phosphate & 1.000 \\
Salt & 0.230 \\
Intox (sorbent) & 0.100 \\
Methionyn & 0.130 \\
Proactive & 0.100 \\
Mineral complex Rovimix ${ }^{2}$ & 0.100 \\
Lysine & 0.160 \\
Millerzyme III $150^{3}$ & 0.015 \\
Sodium sulfate & 0.130 \\
Choline chloride & 0.030 \\
Vitamin complex & \\
\hline Chemical composition, $\mathrm{g} / 100 \mathrm{~g}$ & 0.020 \\
\hline Moisture & \\
Crude protein & 10.40 \\
Metabolic energy, kcal/kg & 16.22 \\
Calcium & 2912.00 \\
Total phosphorus & 4.76 \\
Sodium & 0.77 \\
\hline
\end{tabular}

Note: $1-1 \mathrm{~kg}$ of Proactive contains: bacteria Bacillus subtilis and Bacillus licheniformis, not less than $1 * 10^{12} \mathrm{CFU}$, bacteria of the genus Enterococcus faecium, not less than $5 * 10^{10} \mathrm{CFU}$, fermentation products Lactococcus lactis, Bacillus subtilis, Bacillus licheniformis $100 \mathrm{~g} / 100 \mathrm{~g}$, protease 500 units, cellulase 20000 units, milk thistle meal $20 \mathrm{~g}$, acidity regulator $10 \mathrm{~g}$, betaine $10 \mathrm{~g}$, chitosan $0.1 \mathrm{~g}$, yeast cell walls (mananooligosaccharides) $100 \mathrm{~g}$, natural aluminosilicates - up to $1 \mathrm{~kg} ; 2-1 \mathrm{~kg}$ of premix Rovimix contains: iron (Fe) $35000 \mathrm{mg}$, iodine (J) $1200 \mathrm{mg}$, cobalt (Co) $100 \mathrm{mg}$, copper (Cu) $10000 \mathrm{mg}$, zinc (Zn) $85000 \mathrm{mg}$, manganese (Mn) $90000 \mathrm{mg}$, selenium (Se) $250 \mathrm{mg}$, limestone $\left(\mathrm{CaCO}_{3}\right)$ to $1000 \mathrm{~g} ; 3-1 \mathrm{~kg}$ of Millerzyme III 150 contains: beta-glucanase 26500 units, xylanase 26500 units, cellulase 6000 units, mannanase 200 units, beta-glucosidase 40 units, beta-xylosidase 8 units, amyloglucosidase 32 units, protease 12 units, phytase 500 units; $4-1 \mathrm{~kg}$ of premix Rovimix contains: vitamin A $26666667 \mathrm{IU}$, vitamin $\mathrm{D}_{3} 11000000 \mathrm{IU}$, vitamin E $66670 \mathrm{mg}$ vitamin $\mathrm{K}_{3} 8330 \mathrm{mg}$, vitamin $\mathrm{B}_{1} 8330 \mathrm{mg}$, vitamin $\mathrm{B}_{2} 18330 \mathrm{mg}$, vitamin $\mathrm{B}_{6}$ $13330 \mathrm{mg}$, vitamin $B_{12} 77 \mathrm{mg}$, niacin $100000 \mathrm{mg}$, pantothenic acid $26670 \mathrm{mg}$, folic acid $3000 \mathrm{mg}$, antioxidant/luctanox $120 \mathrm{mg}$, biotin $250 \mathrm{mg}$, limestone $\left(\mathrm{CaCO}_{3}\right)$ to $1000 \mathrm{~g}$.

For the study, 9 eggs were selected from each group of chickens on $30-31,60-61$ and $90-91$ days of the experiment. Extraction of lipids from egg yolks was performed by the method of Folch et al. (1957). The next step in sample preparation was the hydrolysis and methylation of fatty acids of lipids obtained from samples of chicken yolks (Christive, 1982). Analysis of methyl esters of fatty acids was performed on a gas chromatograph Trace GC Ultra (USA) with a flame-ionization detector and an injector with temperature programming on a SPTM-2560 high-polar capillary column (Supelco, USA), length $100 \mathrm{~m}$, with an inner diameter of $0.25 \mathrm{~mm}$ and a thickness of the stationary phase of $0.20 \mu \mathrm{m}$. Chromato- graphy conditions: column temperature $140-240^{\circ} \mathrm{C}$, detector temperature $260{ }^{\circ} \mathrm{C}$. The sample was introduced into the chromatograph using a TriPlus autosampler at a dose of $1 \mu \mathrm{L}$. The duration of the analysis was 65 minutes.

Identification of fatty acids was performed using a standard sample Supelco 37 Component FAME Mix. Quantitative evaluation of the fatty acid spectrum of yolk lipids was performed by the method of internal normalization, determining their content in percent. The study was performed in three parallels. The following fatty acids were determined in chicken egg yolks: myristic (14:0), myristoleic (14:1), pentadecanoic (15:0), pal-

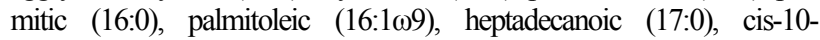
heptadecenoic $(17: 1)$, stearic (18:0), oleic $(18: 1 \omega 9)$, linoleic $(18: 2 \omega 6)$,

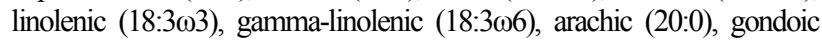

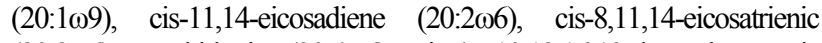

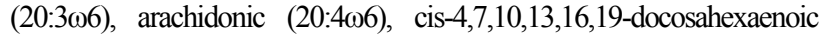

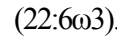

Statistical processing of the obtained results was performed using the ANOVA program, the data in the tables are presented in the form of $\mathrm{x} \pm$ $\mathrm{SD}$ (mean \pm standard deviation). The difference between the values in the groups was determined using the Tukey test. The difference was considered significant at $\mathrm{P}<0.05$ (taking into account the Bonferroni correction).

\section{Results}

Additions of lycopene in doses of 20,40 and $60 \mathrm{mg} / \mathrm{kg}$ or astaxanthin in doses of 10, 20 and $30 \mathrm{mg} / \mathrm{kg}$ of feed did not affect the content of saturated fatty acids: myristine, pentadecanoic, palmitic, heptadecanoic, stearic, arachic and behenic in chicken yolks, which agrees with their FA SFA (Tables 3-5).

\section{Table 3}

The effect of lycopene at a dose of $20 \mathrm{mg} / \mathrm{kg}$ and astaxanthin at a dose of $10 \mathrm{mg} / \mathrm{kg}$ of feed on the content of fatty acids in chicken egg yolks ( $\%$ of the total fatty acid content, $x \pm S D, n=9$ )

\begin{tabular}{|c|c|c|c|}
\hline Acid & Control & LP20 & AST10 \\
\hline Myristic, 14:0 & $0.26 \pm 0.01$ & $0.27 \pm 0.01$ & $0.28 \pm 0.01$ \\
\hline Myristoleic, 14:1 & $0.05 \pm 0.01$ & $0.05 \pm 0.004$ & $0.04 \pm 0.01$ \\
\hline Pentadecanoic, 15:0 & $0.06 \pm 0.004$ & $0.05 \pm 0.01$ & $0.07 \pm 0.004$ \\
\hline Palmitic, $16: 0$ & $26.88 \pm 0.28$ & $27.17 \pm 0.48$ & $27.58 \pm 0.12$ \\
\hline Palmitoleic, $16: 1$ & $0.60 \pm 0.01^{\mathrm{a}}$ & $0.50 \pm 0.03^{\mathrm{ab}}$ & $0.50 \pm 0.01^{\mathrm{b}}$ \\
\hline Heptadecanoic, 17:0 & $2.12 \pm 0.24$ & $2.17 \pm 0.07$ & $2.04 \pm 0.14$ \\
\hline Cis-10-heptadecenoic, 17:1 & $0.06 \pm 0.004^{\mathrm{a}}$ & $0.04 \pm 0.004^{\mathrm{ab}}$ & $0.08 \pm 0.004^{b}$ \\
\hline Stearic, $18: 0$ & $10.36 \pm 0.49$ & $11.09 \pm 0.22$ & $10.09 \pm 0.51$ \\
\hline Oleic, $18: \ln 9 \mathrm{c}$ & $36.57 \pm 0.48$ & $38.16 \pm 0.91$ & $36.41 \pm 0.54$ \\
\hline Linoleic, $18: 2 n 6 c$ & $17.73 \pm 0.35^{\mathrm{a}}$ & $14.89 \pm 0.51^{\mathrm{b}}$ & $25.22 \pm 1.49^{\mathrm{ab}}$ \\
\hline Arachic, 20:0 & $0.03 \pm 0.004$ & $0.02 \pm 0.004$ & $0.02 \pm 0.004$ \\
\hline Gamma-linolenic, $18: 3 \mathrm{n} 6$ & $0.16 \pm 0.004^{\mathrm{ab}}$ & $0.15 \pm 0.01^{\mathrm{a}}$ & $0.20 \pm 0.01^{\mathrm{b}}$ \\
\hline Cis-11-eicosenoic, 20:1 & $0.46 \pm 0.01^{\mathrm{a}}$ & $0.37 \pm 0.01^{\mathrm{b}}$ & $0.46 \pm 0.01^{\mathrm{a}}$ \\
\hline Linolenic, $18: 3 \mathrm{n} 3$ & $0.22 \pm 0.02$ & $0.19 \pm 0.05$ & $0.14 \pm 0.04$ \\
\hline $\begin{array}{l}\text { Cis-11,14-eicosadienoic, } \\
20: 2 n 6\end{array}$ & $0.17 \pm 0.01$ & $0.14 \pm 0.02$ & $0.17 \pm 0.01$ \\
\hline Behenic, 22:0 & $0.05 \pm 0.004$ & $0.06 \pm 0.02$ & $0.05 \pm 0.02$ \\
\hline $\begin{array}{l}\text { Cis-8,11,14- } \\
\text { Eicosatetraenoic, 20:3n6 }\end{array}$ & $0.22 \pm 0.004$ & $0.25 \pm 0.03$ & $0.26 \pm 0.01$ \\
\hline Arachidonic, $20: 4 n 6$ & $3.05 \pm 0.10$ & $3.38 \pm 0.15$ & $2.91 \pm 0.08$ \\
\hline $\begin{array}{l}\text { Cis-4,7,10,13,16,19- } \\
\text { Docosahexaenoic, } 22: 6 n 3\end{array}$ & $1.03 \pm 0.03$ & $1.12 \pm 0.09$ & $1.03 \pm 0.03$ \\
\hline$\Sigma \mathrm{SFA}$ & $39.76 \pm 0.18$ & $40.82 \pm 0.25$ & $40.13 \pm 0.52$ \\
\hline$\Sigma$ UFA & $60.31 \pm 0.18$ & $59.24 \pm 0.26$ & $59.93 \pm 0.52$ \\
\hline$\Sigma$ MUFA & $37.73 \pm 0.48$ & $39.12 \pm 0.91$ & $37.49 \pm 0.51$ \\
\hline$\Sigma$ PUFA & $22.58 \pm 0.40$ & $20.11 \pm 0.67$ & $22.44 \pm 1.01$ \\
\hline$\Sigma \omega 3$ PUFA & $1.25 \pm 0.03$ & $1.31 \pm 0.04$ & $1.17 \pm 0.03$ \\
\hline$\Sigma \omega 6$ PUFA & $21.33 \pm 0.40$ & $18.18 \pm 0.65$ & $21.27 \pm 1.03$ \\
\hline$\omega 3 / \omega 6$ PUFA & $17.12 \pm 0.47^{\mathrm{a}}$ & $14.36 \pm 0.50^{b}$ & $18.22 \pm 1.29^{\mathrm{ab}}$ \\
\hline
\end{tabular}

Note: different uppercase letters $a, b$ indicate values that probably differed in one row of the table $(\mathrm{P}<0.05)$ by comparison with Tukey test with Bonferroni correction.

Lycopene did not affect the content of the vast majority of monounsaturated fatty acids and their $\Sigma$ MUFA, and only at a dose of $20 \mathrm{mg} / \mathrm{kg}$ of feed reduced $(\mathrm{P}<0.05)$ the content of cis-11-eicosenoic acid in egg yolks compared to control. Additions of astaxanthin at a dose of $10 \mathrm{mg} / \mathrm{kg}$ of feed reduced $(\mathrm{P}<0.05)$ the content of palmitoleic by increasing $(\mathrm{P}<0.05)$ 
the proportion of cis-10-heptadecenoic acid in the lipids of egg yolks. At doses of 20 and $30 \mathrm{mg} / \mathrm{kg}$ of compound feed, astaxanthin did not change the ratio of monounsaturated fatty acids in chicken egg yolks, which is consistent with $\Sigma$ MUFA (Tables 3-5).

\section{Table 4}

The effect of lycopene at a dose of $40 \mathrm{mg} / \mathrm{kg}$ and astaxanthin at a dose of $20 \mathrm{mg} / \mathrm{kg}$ of feed on the fatty acid content in chicken egg yolks ( $\%$ of the total fatty acid content, $x \pm S D, n=9$ )

\begin{tabular}{|c|c|c|c|}
\hline Acid & Control & LP40 & AST20 \\
\hline Myristic, 14:0 & $0.24 \pm 0.01$ & $0.28 \pm 0.02$ & $0.29 \pm 0.04$ \\
\hline Myristoleic, $14: 1$ & $0.03 \pm 0.004$ & $0.05 \pm 0.004$ & $0.04 \pm 0.01$ \\
\hline Pentadecanoic, 15:0 & $0.06 \pm 0.004$ & $0.06 \pm 0.001$ & $0.06 \pm 0.01$ \\
\hline Palmitic, 16:0 & $27.07 \pm 0.11$ & $26.26 \pm 0.40$ & $26.65 \pm 0.16$ \\
\hline Palmitoleic, $16: 1$ & $0.49 \pm 0.01$ & $0.56 \pm 0.01$ & $0.52 \pm 0.08$ \\
\hline Heptadecanoic, 17:0 & $1.85 \pm 0.08$ & $2.05 \pm 0.09$ & $2.04 \pm 0.44$ \\
\hline Cis-10-heptadecenoic, 17:1 & $0.07 \pm 0.004$ & $0.08 \pm 0.01$ & $0.08 \pm 0.01$ \\
\hline Stearic, $18: 0$ & $11.25 \pm 0.09$ & $11.37 \pm 0.27$ & $11.11 \pm 1.50$ \\
\hline Oleic, $18: \ln 9 \mathrm{c}$ & $34.33 \pm 0.19$ & $36.27 \pm 1.10$ & $36.73 \pm 2.20$ \\
\hline Linoleic, $18: 2 \mathrm{n} 6 \mathrm{c}$ & $18.46 \pm 0.37$ & $16.73 \pm 0.62$ & $16.83 \pm 0.50$ \\
\hline Arachic, 20:0 & $0.21 \pm 0.004$ & $0.21 \pm 0.01$ & $0.23 \pm 0.01$ \\
\hline Gamma-linolenic, 18:3n6 & $0.03 \pm 0.004^{\mathrm{ab}}$ & $0.03 \pm 0.001^{\mathrm{a}}$ & $0.02 \pm 0.001^{\mathrm{b}}$ \\
\hline Cis-11-eicosenoic, 20:1 & $0.37 \pm 0.02$ & $0.36 \pm 0.02$ & $0.39 \pm 0.05$ \\
\hline Linolenic, $18: 3 \mathrm{n} 3$ & $0.19 \pm 0.01$ & $0.21 \pm 0.01$ & $0.20 \pm 0.01$ \\
\hline $\begin{array}{l}\text { Cis-11,14-eicosadienoic, } \\
\text { 20:2n6 }\end{array}$ & $0.19 \pm 0.004$ & $0.19 \pm 0.02$ & $0.18 \pm 0.02$ \\
\hline Behenic, 22:0 & $0.06 \pm 0.001$ & $0.05 \pm 0.004$ & $0.06 \pm 0.01$ \\
\hline $\begin{array}{l}\text { Cis-8,11,14- } \\
\text { Eicosatetraenoic, 20:3n6 }\end{array}$ & $0.30 \pm 0.01$ & $0.28 \pm 0.02$ & $0.31 \pm 0.06$ \\
\hline Arachidonic, $20: 4 n 6$ & $3.59 \pm 0.06$ & $3.62 \pm 0.14$ & $3.11 \pm 0.75$ \\
\hline $\begin{array}{l}\text { Cis-4,7,10,13,16,19- } \\
\text { Docosahexaenoic, } 22: 6 n 3\end{array}$ & $1.29 \pm 0.09$ & $1.38 \pm 0.14$ & $1.21 \pm 0.33$ \\
\hline$\Sigma$ SFA & $40.74 \pm 0.16$ & $40.28 \pm 0.60$ & $40.44 \pm 1.19$ \\
\hline$\Sigma$ UFA & $59.34 \pm 0.16$ & $59.78 \pm 0.59$ & $59.63 \pm 1.19$ \\
\hline$\Sigma$ MUFA & $35.29 \pm 0.18$ & $37.32 \pm 1.10$ & $37.77 \pm 2.34$ \\
\hline$\Sigma$ PUFA & $24.05 \pm 0.27^{\mathrm{a}}$ & $22.46 \pm 0.51^{b}$ & $21.86 \pm 1.20^{\mathrm{ab}}$ \\
\hline$\Sigma \omega 3$ PUFA & $1.48 \pm 0.08$ & $1.60 \pm 0.15$ & $1.41 \pm 0.33$ \\
\hline$\Sigma \omega 6$ PUFA & $22.57 \pm 0.35$ & $20.86 \pm 0.60$ & $20.45 \pm 0.95$ \\
\hline$\omega 3 / \omega 6$ PUFA & $15.33 \pm 1.11$ & $13.24 \pm 1.42$ & $15.61 \pm 3.57$ \\
\hline
\end{tabular}

Note: see Table. 3.

As for polyunsaturated fatty acids, lycopene at doses of 40 and $60 \mathrm{mg} / \mathrm{kg}$ of feed for 30 days did not affect their ratio and $\Sigma$ PUFA, and at a dose of $20 \mathrm{mg} / \mathrm{kg}$ of feed caused a decrease in the proportion of linoleic $(\mathrm{P}<0.05)$ and cis-eicosenoic $(\mathrm{P}<0.05)$ acids in the structure of lipid yolks of chicken eggs. Astaxanthin did not affect the ratio of polyunsaturated fatty acids except for gamma-linolenic acid, the proportion of which increased $(\mathrm{P}<0.05)$ at a dose of $10 \mathrm{mg} / \mathrm{kg}$ of feed, and at a dose of $20 \mathrm{mg} / \mathrm{kg}$ of feed decreased $(\mathrm{P}<0.05)$ compared with lycopene. Addition of astaxanthin in the diet of laying hens at a dose of $30 \mathrm{mg} / \mathrm{kg}$ contributed to a decrease $(\mathrm{P}<0.05)$ in the proportion of cis-4,7,10,13,16,19-docosahexaenoic acid, which belongs to $\omega 3$ PUFA, in yolk lipids compared to control.

The total content of polyunsaturated acids $\Sigma$ PUFA decreased ( $\mathrm{P}<$ 0.05 ) in the fraction of yolk lipids only under the influence of lycopene supplements at a dose of $20 \mathrm{mg} / \mathrm{kg}$ of feed. In other doses, lycopene and astaxanthin in all doses in the diet of chickens did not change $\Sigma$ PUFA in egg yolks (Tables 3-5).

Feeding of laying hens with lycopene and astaxanthin supplements did not affect $\Sigma \omega 3$ PUFA and $\Sigma \omega 6$ PUFA except for astaxanthin dose of $30 \mathrm{mg} / \mathrm{kg}$, which reduced $(\mathrm{P}<0.05)$ the ratio of $\Sigma \omega 3$ PUFA in egg yolks compared to controls. Lycopene supplements at a dose of $20 \mathrm{mg} / \mathrm{kg}$ decreased $(\mathrm{P}<0.05)$, and astaxanthin supplements at a dose of $30 \mathrm{mg} / \mathrm{kg}$ of feed increased $(\mathrm{P}<0.05) \omega 3 / \omega 6$ PUFA in egg yolk lipids.

\section{Discussion}

Almost all egg lipids are contained in the yolk. About $65 \%$ of yolk lipids are triglycerides, while phospholipids, cholesterol, and carotenoids are $30 \%, 4 \%$, and $<1 \%$, respectively (Hatta et al., 2008). An important factor that determines the dietary properties of edible eggs is the presence of fatty acids in the yolks and their ratio. The fatty acid composition of egg yolk can be influenced by the feed formulation, obtaining eggs enriched with polyunsaturated fatty acids (Surai, 2000). As can be seen from the obtained data (Tables 3-5), in chicken egg yolks the main saturated fatty acids that are part of the lipid structure are palmitic and stearin. The main unsaturated acids of chicken egg yolks receiving supplements of lycopene and astaxanthin, regardless of their content in the diet were oleic, linoleic and arachidonic. Our data confirmed that based on standardized poultry feed, approximately $30-35 \%$ of the total fatty acids are saturated fatty acids (SFA), 40-45\% are monounsaturated fatty acids (MUFA) and 20$25 \%$ are polyunsaturated fatty acids (PUFA) (Anton, 2007). In this case, the lycopene or astaxanthin diet of chickens did not significantly affect the ratio of saturated and unsaturated fatty acids in the lipid structure of egg yolks, which is consistent with the results obtained using a supplement containing $1 \%$ dried tomato paste and $1 \%$ sweet red pepper as carotenoid sources. laying hens (Omri et al., 2019).

\section{Table 5}

Effect of lycopene at a dose of $60 \mathrm{mg} / \mathrm{kg}$ and astaxanthin at a dose of $30 \mathrm{mg} / \mathrm{kg}$ of feed on fatty acid content in chicken egg yolks ( $\%$ of the total fatty acid content, $\mathrm{x} \pm \mathrm{SD}, \mathrm{n}=9$ )

\begin{tabular}{|c|c|c|c|}
\hline Acid & Control & LP60 & AST30 \\
\hline Myristic, $14: 0$ & $0.25 \pm 0.01$ & $0.28 \pm 0.01$ & $0.29 \pm 0.01$ \\
\hline Myristoleic, 14:1 & $0.03 \pm 0.004$ & $0.04 \pm 0.004$ & $0.05 \pm 0.004$ \\
\hline Pentadecanoic, 15:0 & $0.06 \pm 0.001$ & $0.06 \pm 0.01$ & $0.06 \pm 0.004$ \\
\hline Palmitic, $16: 0$ & $27.90 \pm 0.22$ & $28.15 \pm 0.19$ & $28.04 \pm 0.09$ \\
\hline Palmitoleic, 16:1 & $0.87 \pm 0.49$ & $1.91 \pm 0.07$ & $2.21 \pm 0.13$ \\
\hline Heptadecanoic, 17:0 & $0.20 \pm 0.01$ & $0.21 \pm 0.01$ & $0.18 \pm 0.01$ \\
\hline Cis-10-heptadecenoic, 17:1 & $0.08 \pm 0.004$ & $0.07 \pm 0.004$ & $0.08 \pm 0.004$ \\
\hline Stearic, $18: 0$ & $12.60 \pm 0.34$ & $11.87 \pm 0.23$ & $12.64 \pm 0.30$ \\
\hline Oleic, $18: \ln 9 \mathrm{c}$ & $34.05 \pm 0.47$ & $34.45 \pm 0.69$ & $34.46 \pm 0.65$ \\
\hline Linoleic, $18: 2 \mathrm{n} 6 \mathrm{c}$ & $17.02 \pm 0.35$ & $16.63 \pm 0.20$ & $16.14 \pm 0.45$ \\
\hline Arachic, 20:0 & $0.18 \pm 0.01$ & $0.19 \pm 0.01$ & $0.18 \pm 0.01$ \\
\hline Gamma-linolenic, 18:3n6 & $0.04 \pm 0.001$ & $0.03 \pm 0.004$ & $0.02 \pm 0.004$ \\
\hline Cis-11-eicosenoic, 20:1 & $0.35 \pm 0.04$ & $0.34 \pm 0.02$ & $0.38 \pm 0.01$ \\
\hline Linolenic, $18: 3 \mathrm{n} 3$ & $0.22 \pm 0.01$ & $0.20 \pm 0.01$ & $0.21 \pm 0.004$ \\
\hline $\begin{array}{l}\text { Cis-11,14-eicosadienoic, } \\
\text { 20:2n6 }\end{array}$ & $0.18 \pm 0.004$ & $0.19 \pm 0.01$ & $0.21 \pm 0.01$ \\
\hline Behenic, 22:0 & $0.07 \pm 0.01$ & $0.06 \pm 0.01$ & $0.07 \pm 0.004$ \\
\hline $\begin{array}{l}\text { Cis-8,11,14- } \\
\text { Eicosatetraenoic, 20:3n6 }\end{array}$ & $=0.01$ & 0.01 & \pm 0.01 \\
\hline Arachidonic, $20: 4 \mathrm{n} 6$ & $4.14 \pm 0.18$ & $3.73 \pm 0.40$ & $3.40 \pm 0.10$ \\
\hline $\begin{array}{l}\text { Cis-4,7,10,13,16,19- } \\
\text { Docosahexaenoic, } 22: 6 n 3\end{array}$ & $1.53 \pm 0.02^{\mathrm{a}}$ & $1.37 \pm 0.15^{\mathrm{ab}}$ & $1.14 \pm 0.02^{\mathrm{b}}$ \\
\hline$\Sigma$ SFA & $41.26 \pm 0.51$ & $40.81 \pm 0.41$ & $41.46 \pm 0.31$ \\
\hline$\Sigma$ UFA & $58.81 \pm 0.51$ & $59.26 \pm 0.40$ & $58.62 \pm 0.30$ \\
\hline$\Sigma$ MUFA & $35.38 \pm 0.92$ & $36.82 \pm 0.78$ & $37.18 \pm 0.54$ \\
\hline$\Sigma$ PUFA & $24.43 \pm 0.52$ & $22.45 \pm 0.68$ & $21.44 \pm 0.53$ \\
\hline$\Sigma \omega 3$ PUFA & $1.75 \pm 0.03^{\mathrm{a}}$ & $1.57 \pm 0.16^{\mathrm{ab}}$ & $1.36 \pm 0.01^{\mathrm{b}}$ \\
\hline$\Sigma \omega 6$ PUFA & $21.68 \pm 0.50$ & $20.88 \pm 0.53$ & $20.08 \pm 0.52$ \\
\hline$\omega 3 / \omega 6$ PUFA & $12.39 \pm 0.24^{\mathrm{a}}$ & $13.44 \pm 1.05^{\mathrm{ab}}$ & $14.81 \pm 0.41^{\mathrm{b}}$ \\
\hline
\end{tabular}

Note: see Table 3 .

In our experiment, the content of $\Sigma \omega 3$ PUFA in chicken egg yolks was affected only by astaxanthin at a dose of $30 \mathrm{mg} / \mathrm{kg}$ of feed, which reduced this figure due to the proportion of cis-4,7,10,13,16,19-docosahexaenoic acid. Similar data were obtained using dietary supplements for chickens containing $5 \%$ dried tomato waste as a source of carotenoids (lycopene), which at high doses inhibited the uptake and deposition of n-3 PUFA in egg yolk (Panaite et al., 2019). Known and opposite results were obtained by adding flax seeds, paprika and marigolds in the feed of laying hens. This experiment revealed an increase in the content of $\alpha$-linolenic, eicosapentaenoic and docosahexaenoic acids in egg yolk (Spasevski et al., 2016). In a study using additives of $1.5 \%$ and $3.0 \%$ krill meal in the diet of chickens, there was an increase in egg yolk colour and an increase in astaxanthin, vitamin A, vitamin E, an increase in $\mathrm{n}-3$ fatty acids, especially docosahexaenoic (Prommetta et al., 2020).

Diets supplemented with $10 \mathrm{~g} / \mathrm{kg}$ or $20 \mathrm{~g} / \mathrm{kg}$ marigolds increased C16:0 and C18:0 levels and decreased C16:1 (n-7) and C18: 1 (n-9) levels in egg yolk. In addition, the diet, including marigolds, increased the total content of saturated fatty acids (SFA) and decreased monounsaturated fatty acids (MUFA) in egg yolk. The conflicting results obtained in the experiments are difficult to explain due to the insufficient number of 
reports on this issue. However, it can be assumed that the use of carotenoids in pure form, as well as in the form of supplements of plant or animal origin in the diet of chickens can affect both the intensity of assimilation of carotenoids and the lipid profile of egg yolks.

Despite the fact that the optimal ratio of $\omega 3 / \omega 6$ PUFA is considered to be at the level of 4-1:1 in the human diet (Alagawany et al., 2019) and that for this many ways of adjusting the diet of productive birds have been developed (Konieczka et al., 2018), we failed to achieve this ratio in egg yolks by enriching the diet of laying hens with oil extracts of lycopene or astaxanthin. This may be due to the low oil content in the diet of chickens, as well as the chemical composition of sunflower oil, which was the basis of lycopene and astaxanthin supplements.

In general, the results of this study are difficult to compare with the literature, as most studies focus on the effect on the lipid composition of egg yolks (Omidi et al., 2015; Cherian \& Quezada, 2016; Ehr et al., 2017; Buckiuniene, 2018; Świątkiewicz et al., 2020) or their compositions with carotenoids in the diet of chickens, where it is difficult to distinguish the key factors that determine the composition of fatty acids in the structure of lipids.

\section{Conclusions}

Additions of oil extracts of lycopene at doses of 30,40 and $60 \mathrm{mg} / \mathrm{kg}$ and astaxanthin at doses of 10,20 and $30 \mathrm{mg} / \mathrm{kg}$ to feed for 30 days for laying hens did not affect the content of saturated fatty acids, but changed the ratio of the individual monounsaturated and polyunsaturated fatty acids belonging to $\omega 3$ and $\omega 6$ PUFA, which can be used to correct the lipid profile of egg yolks by choosing the dose and type of carotenoids in the diet of laying hens.

\section{References}

Alagawany, M., Elnesr, S. S., Farag, M. R., Abd El-Hack, M. E., Khafaga, A. F., Taha, A. E., Tiwari, R., Yatoo, M. I., Bhatt, P., Khurana, S. K., \& Dhama, K. (2019). Omega-3 and omega-6 fatty acids in poultry nutrition: Effect on production performance and health. Animals, 9(8), 573.

Anton, M. (2007). Composition and structure of hen egg yolk. In: Huopalahti, R., Lopez-Fandino, R. (Eds.). Bioactive egg compounds. Springer-Verlag, Heidelberg. Pp. 17-24.

Boschetti, E., Bordoni, A., Meluzzi, A., Castellini, C., Dal Bosco, A., \& Sirri, F. (2016). Fatty acid composition of chicken breast meat is dependent on genotype-related variation of FADS1 and FADS2 gene expression and desaturating activity. Animal, 10(4), 700-708.

Buckiuniene, V., Alencikiene, G., Aldona, M., Racevičiūtè-Stupelienė, A., Bliznikas, S., \& Gruzauskas, R. (2018). Effect of sunflower and rapeseed oil, organic and inorganic selenium and vitamin $\mathrm{E}$ in the diet on yolk fatty acids profile, malondialdehydes concentration and sensory quality of laying hens eggs. Veterinarija ir Zootechnika, 76(98), 21-28.

Cherian, G., \& Quezada, N. (2016). Egg quality, fatty acid composition and immunoglobulin Y content in eggs from laying hens fed full fat camelina or flax seed. Journal of Animal Science and Biotechnology, 7, 15.

Christie, W. W. (1982). Lipid analysis: Isolation, separation, identification, and structural analysis of lipids. Pergamon Press, Oxford.
Danchuk, V., Trach, V., Midyk, S., Danchuk, O., Ushkalov, V., \& Kepple, O. (2019). The fatty acids content in the liver of japanese quails after the chemical treatment of hatching eggs. Food Science and Technology, 13(2), 58-64.

Ehr, I. J., Persia, M. E., \& Bobeck, E. A. (2017). Comparative omega-3 fatty acid enrichment of egg yolks from first-cycle laying hens fed flaxseed oil or ground flaxseed. Poultry Science, 96(6), 1791-1799.

Folch, J., Lees, M., \& Sloane-Stanley, G. H. (1957). A simple method for the isolation and purification of total lipides from animal tissues. Journal of Biological Chemistry, 226(1), 497-509.

Godos, J., Micek, A., Brzostek, T., Toledo, E., Iacoviello, L., Astrup, A., Franco, O. H., Galvano, F., Martinez-Gonzalez, M. A., \& Gross, G. (2020). Egg consumption and cardiovascular risk: A dose-response meta-analysis of prospective cohort studies. European Journal of Nutrition, in press.

Hatta, H., Kapoor, M., \& Juneja, L. (2008). Bioactive components in egg yolk. In: Mine, Y. (Ed.). Egg bioscience and biotechnology. John Wiley \& Sons, Ltd., Hoboken. Pp. 185-237.

Keum, M.-C., An, B.-K., Shin, K.-H., \& Lee, K.-W. (2018). Influence of dietary fat sources and conjugated fatty acid on egg quality, yolk cholesterol, and yolk fatty acid composition of laying hens. Revista Brasileira de Zootecnia, 47, e20170303.

Konieczka, P., Barszcz, M., Choct, M., \& Smulikowska, S. (2018). The interactive effect of dietary n-6: n-3 fatty acid ratio and vitamin E level on tissue lipid peroxidation, DNA damage in intestinal epithelial cells, and gut morphology in chickens of different ages. Poultry Science, 97(1), 149-158.

Nimalaratne, C., \& Wu, J. (2015). Hen egg as an antioxidant food commodity: A review. Nutrients, 7(10), 8274-8293.

Omidi, M., Rahimi, S., \& Karimi Torshizi, M. A. (2015). Modification of egg yolk fatty acids profile by using different oil sources. Veterinary Research Forum, 6(2), 137-141.

Omri, B., Chalghoumi, R., Izzo, L., Ritieni, A., Lucarini, M., Durazzo, A., Abdouli, H., \& Santini, A. (2019). Effect of dietary incorporation of linseed alone or together with tomato-red pepper mix on laying hens' egg yolk fatty acids profile and health lipid indexes. Nutrients, 11(4), 813.

Panaite, T. D., Nour, V., Vlaicu, P. A., Ropota, M., Corbu A. R. \& Saracila, M. (2019). Flaxseed and dried tomato waste used together in laying hens diet. Archives of Animal Nutrition, 73(3), 222-238.

Prommetta, K., Attamangkune, S., \& Ruangpanit, Y. (2020). Krill meal enhances antioxidant levels and n-3 fatty acid content of egg yolk from laying hens fed a low-pigment diet. The Journal of Poultry Science, 57(3), 192-199.

Shinn, S. E., Proctor, A., \& Baum, J. I. (2018). Egg yolk as means for providing essential and beneficial fatty acids. Journal of the American Oil Chemists' Society, 95, 5-11.

Spasevski, N., Čolović, D., Rakita, S., Ikonić, P., Đuragić, O., Banjac, V., \& Vukmirović, Đ. (2016). Fatty acid composition and $\beta$-carotene content in egg yolk of laying hens fed with linseed, paprika and marigold. Contemporary Agriculture, $65,15-22$

Surai, P. F. (2000). Effect of selenium and vitamin E content of the maternal diet on the antioxidant system of the yolk and the developing chick. British Poultry Science, 41, 235-243.

Świątkiewicz, S., Arczewska-Włosek, A., Szczurek, W., Calik, J., Bederska-Łojewska, D., Orczewska-Dudek, S., Muszyński, S., Tomaszewska, E., \& Józefiak, D. (2020). Algal oil as source of polyunsaturated fatty acids in laying hens nutrition: Effect on egg performance, egg quality indices and fatty acid composition of egg yolk lipids. Annals of Animal Science, 20(3), 961-973.

Yu, Z., Wang, N., Ahn, D. U., \& Ma, M. (2019). Long term egg yolk consumption alters lipid metabolism and attenuates hyperlipidemia in mice fed a high-fat diet based on lipidomics analysis. European Journal of Lipid Science and Technology, 121, 1800496. 